\title{
Influences of the Thalamus on the Survival of Subplate and Cortical Plate Cells in Cultured Embryonic Mouse Brain
}

\author{
David J. Price and R. Beau Lotto \\ Department of Physiology, University Medical School, Edinburgh EH8 9AG, United Kingdom
}

The afferent and efferent connections of the cerebral neocortex develop simultaneously toward the end of embryogenesis. At this stage, the neocortex comprises two main cell-dense layers: the thicker and more superficial cortical plate (future layers 2-6) and the thinner underlying subplate. Many early thalamocortical projections temporarily innervate the subplate before leaving it to locate their ultimate targets in the overlying cortical plate. The subplate then disappears. In this study, we performed in vitro experiments on late embryonic murine brain to test whether the thalamus can influence the survival of cortical plate and subplate cells at this stage. In isolated organotypic cortical explants from embryonic day 19 mice, most of the cells that had formed the subplate died. Coculture with a thalamic ex- plant prevented this loss; coculture with additional cortical or cerebellar explants did not. By contrast, many cells in or destined for the cortical plate survived even in isolated cortical explants; coculture with a thalamic explant did not alter the numbers of these cells that survived. Our results suggest that the thalamus provides trophic support for subplate cells but not for late embryonic cortical plate cells. In vivo, a loss of thalamicderived trophic support for the subplate late in embryogenesis, consequent on the movement of thalamocortical axons into the cortical plate, may contribute to subplate death.

Key words: cortical plate; corticothalamic projection; growth factors; mouse; organotypic culture; subplate; thalamocortical projection; trophism
In the adult brain, each cortical layer has a specific pattern of connections with subcortical and cortical regions. For example, corticofugal axons originate from deep cortical layers 5 and 6 , thalamocortical afferents terminate mainly in cortical layer 4 , and corticocortical connections originate and terminate in cortical layers 2 and 3. During fetal life, the laminar structure of the developing cortex is much simpler and comprises the marginal zone (future layer 1), cortical plate (future layers 2-6), and a transient structure known as the subplate (a band of cells lying below the developing cortical plate) (for review, see Bayer and Altman, 1991). Before birth, distinct layers are not yet visible in the cortical plate, and cells destined for the most superficial cortical layers are still migrating from the proliferative zone (or ventricular zone) toward the cortical plate. At this time, the subplate receives a temporary innervation from the thalamus, and these thalamocortical axons later move into the rapidly differentiating cortical plate to inncrvate their ultimate targets (revicwed by Allendoerfer and Shatz, 1994). Once thalamic axons have left the subplate, neurons in this region begin to degenerate and many die before adulthood (Allendoerfer and Shatz, 1994).

In the mouse, the subplate is most clearly detected in the $5 \mathrm{~d}$ before birth, and it disappears shortly after birth (Wood et al., 1992; Gillies and Price, 1993b). The mechanisms that control the different fates of the cortical plate and subplate are unknown. One possibility is that the behavior of the thalamocortical afferents during this crucial phase of development plays an important role. In this study, we used organotypic explant cultures, which retain many of the in vivo features of the neocortex, to examine the

\footnotetext{
Received Dec. 11, 1995; revised Feb. 26, 1996; accepted Feb. 28, 1996.

This work was supported by the Medical Research Council and The Welleome Trust. We thank Katy Gillies and Clare McLauchlan for their help.

Correspondence should be addressed to Dr. D. J. Price, Department of Physiology, University Medical School, Teviot Place, Edinburgh EH8 9AG, United Kingdom.

Copyright $\odot 1996$ Society for Neuroscience $0270-6474 / 96 / 163247-09 \$ 05.00 / 0$
}

ability of cells in the late embryonic cortex to develop and survive in isolation from extracortical influences. We then tested whether the thalamus can affect the viability of cortical and subplate cells at this stage.

\section{MATERIALS AND METHODS}

Animals. BALB/c mice from an isolated laboratory colony were mated overnight, and the females were removed the following day, which was deemed E1.

Injections. Pregnant mice were injected on E13, E14, E15, or F17 with bromodeoxyuridine (BrdU) $\left(70 \mu \mathrm{g} \cdot \mathrm{gm}^{-1}\right.$ in sterile saline, i.p.); these injections were timed to label populations of cells mainly in the subplate and deep cortical layer 6 (E13 injections), layers 5 and 6 (E14 injections), layer 4 (E15 injections), or layers $2 / 3$ (E17 injections) on the day of their generation (Wood et al., 1992; Gillies and Price, 1993a). Some of the mice that had been injected with BrdU on E13 were also injected on E17 with tritiated thymidine $\left(3.0 \mathrm{TBq} \cdot \mathrm{mmol}^{-1}\right.$; DuPont NEN, Boston, MA; NET-027Z; $0.25 \mathrm{MBq} \cdot \mathrm{gm}{ }^{-1}$, i.p.).

Dissections. Pregnant mice were anesthetized decply with urcthane $(0.3$ $\mathrm{ml}$ of a $25 \%$ solution in normal saline, i.p.) on E15 or E19, and the fetuses were removed by cesarean section and decapitated. Following the methods described in Rennie et al. (1994) and Lotto and Price (1994, 1995), the posterior half of each cerebral hemisphere and thalamus (and the cerehellum for some control experiments) were isolated in chilled oxygenated Earle's balanced salt solution (Sigma, St. Louis, MO) and sliced at $350 \mu \mathrm{m}$ on a Mcllwain tissue chopper.

Organotypic cultures. Cortical explants were obtained on E19) (the slices were oriented parasagittally) and thalamic explants were dissected from E15 mice. These explants were arranged on collagen-coated filters (Costar; Transwell-col chambers with $3 \mu \mathrm{m}$ pores) suspended in chemically defined serum-free medium (Romijn et al., 1984); the filters and medium had been preincubated at $37^{\circ} \mathrm{C}$ in $5 \% \mathrm{CO}_{2}$ for $2 \mathrm{hr}$. Some of the cortical explants from animals injected with $\mathrm{BrdU}$ on $\mathrm{E} 13$ and $\left[{ }^{3} \mathrm{H}\right]$ thymidine on E17 $(n=6)$ and from animals injected with BrdU on E14 $(n$ $=6)$, E15 $(n=6)$, or E17 $(n=6)$ were cultured with their ventricular side touching a thalamic explant. Other cortical explants from these animals were cultured alone, that is, with no other tissue in the same well $(n=10$ for E13 injections; $n=6$ each for E14, E15, and E17 injections). For control purposes, some cortical explants from animals injected with BrdU on E13 were cultured with their ventricular side touching another E19 
cortical explant $(n=4)$ or cerebellar explant $(n=6)$. At the same time that the cultures were set up, some fetal brains were fixed in $4 \%$ paraformaldehyde so that patterns of labeling in vivo before culture could be estahlished. A few mice injected with BrdU on E13 or E14 were allowed to give birth, and the offspring developed until postnatal day 21 (P21), at which age they were given an overdose of sodium pentobarbitone $(6 \mathrm{mg}$, i.p.) and perfused transcardially with $4 \%$ paraformaldehyde.

Most of the tissues were cultured for $10 \mathrm{~d}$, with the exception of four cultures of E13-labeled cortex grown alone, which were fixed after only 3 d. Four days before the end of the $10 \mathrm{~d}$ period, thalamic and cerebellar (control) explants were pressure-injected through a sterile glass micropipette (tip diameter $\sim 50 \mu \mathrm{m}$ ) with $1 \mu \mathrm{l}$ of a $20 \mu \mathrm{g} \cdot \mathrm{ml}^{-1}$ solution of DiI. This technique could be completed very rapidly (within a few minutes of opening the culture dishes). Because cortical slices grown without a thalamus were always in the same culture dishes as those grown with a thalamus (although in different wells), uninjected cultures (i.e., those lacking a thalamus) were removed from the incubator for exactly the same lemgth of time as the injected cultures. As has been found by others (Bolz et al., 1990; Molnar and Blakemore, 1991), Dil was not toxic to the cultures, and infections were not introduced by the injections. This method produced intense, localized injection sites in the thalamic explants and allowed us to visualize outgrowth from them. In our hands, it gave more powerful labeling than incubating the explants with DiI before culture. Injecting DiI after fixation was not feasible because a prolonged period in fixative was then required, and this was detrimental to the BrdU labeling.

Immunohistochemistry and autoradiography for BrdU and $/{ }^{3} \mathrm{H} /$ thymidine. Fixed cultured explants that contained BrdU or both BrdU and $\left[{ }^{3} \mathrm{H}\right]$ thymidine were embedded in paraffin wax and sectioned in the plane of the cortical explant at $10 \mu \mathrm{m}$. Some brains (obtained on E19 and P21; see above) that had not been cultured and also contained these labels were also sectioned at $10 \mu \mathrm{m}$. The sections were mounted on glass slides and reacted to reveal BrdU labeling following the protocol detailed in Gillies and Price (1993a). Those sections that contained $\left[{ }^{3} \mathrm{H}\right]$ thymidine were dipped in Ilford $\mathrm{K} 5$ emulsion $\left(1: 1\right.$ with $\left.\mathrm{H}_{2} \mathrm{O}\right)$, stored at $4^{\circ} \mathrm{C}$ for $1-4$ weeks, and then developed with Kodak D19 developer and fixed in Ilford Hypam. Slides were then counterstained in cresyl fast violet and coverslipped.

Quantification. Sections labeled with tritiated thymidine and/or BrdU were photographed under dark- and/or bright-field illumination. The positions and densities of BrdU-labeled cells were quantified from camera lucida drawings. As demonstrated previously (del Rio and Soriano, 1989; Gillies and Price, 1993a), BrdU-labeled cells fell into one of two categories: densely labeled cells, in which more than half of the area of the nucleus was labeled, and lightly labeled cells, with a smaller area of nuclear label. This distinction was very important, because dense labeling of a cell indicated that it underwent its final mitosis on the day of injection. Although a few lightly labeled cells may also have becn born at the time of BrdU injection (if the beginning or end of a pulse of injected BrdU coincided with a cell just ending or just beginning its synthesis of DNA), the vast majority were likely to have been the result of subsequent divisions of labeled stem cells after the clearance of injected BrdU. The classification of cells as densely or lightly labeled was made by eye, and previous work has shown that this method gives results that are indistinguishable from those obtained with tritiated thymidine (Smart and Smart, 1982; Gillies and Price, 1993a). In this study, we quantified only densely labeled BrdU-labeled cells because the birthdates of lightly labeled cells were uncertain.

Camera lucida drawings were made of the positions of all the densely labeled cells (referred to from now on as "BrdU labeled cells") in parasagittal sections from the posterior half of the cortex before and after culture, or from mice aged P21. Between four and six adjacent sections of the cortex were selected. Where brains before culture, or at P21, were being studied, these sections were taken one third of the distance between the medial and lateral edges of the brain (this was the level from which cultures were made and at which distortions attributable to the curvature of the cortex in the coronal plane were minimal); where cultured slices were being studied, these sections were from the center of the cultures, so that the full depth from pia to ventricular zone was present. On each drawing, 1-mm-wide tranches through the entire cortical depth were divided into bins. Where we were interested in the relative portions of the labeled cells before and after culture, the cortical depth was divided into 10 bins of equal depth; where we were interested in absolute densities, bins of $0.1 \mathrm{~mm}$ depth were used. The numbers of labeled cells in each bin were counted and displayed as histograms. These methods follow those described in Gillies and Price (1993a).

\section{RESULTS}

\section{Influence of the thalamus on subplate cells}

Figure 1, $a$ and $b$, illustrates the positions of the cells born on E13 (BrdU-labeled) and E17 ( $\left.{ }^{3} \mathrm{H}\right]$ thymidine-labeled) in the cortical slices as they went into culture on E19. Many subplate cells, present just below the cortical plate, were labeled with BrdU (Fig. $1 a)$; a few labeled cells were also present in the deep cortical plate and the marginal zone (BrdU-labeled cells in the marginal zone are not seen in Fig. $1 a$ but are present in other sections; see quantified data in Fig. $7 a$ ). $\left[{ }^{3} \mathrm{H}\right]$ thymidine-labeled layer $2 / 3$ cells were still, for the most part, within the ventricular and subventricular zones below the subplate (Fig. $1 b$; this shows the same section as in Fig. $1 a$ in dark-field).

After $10 \mathrm{~d}$ of culture with thalamus, many E13-BrdU-labeled cells were seen (Figs. $1 c, 2 d, f$ ). The label was nuclear and at high magnification had the appearance of that in healthy cells (Gillies and Price, 1993a). As was the case before culture, these cells were distributed in a band in the cortical slices, although the band had broadened in line with the recognized expansion of slices that occurs under these conditions in vitro (Gillies and Price, 1993b). The labeled cells were near the interface between the cortical and thalamic explants; that is, they no longer occupied a central position in the cortical explants (compare Fig. $1 a$ with Figs. $1 c$ or $2 d$ ). It seemed most likely that this was because the intermediate, subventricular, and ventricular zones shrank as cells continued to migrate to the cortical plate in culture. Evidence for this is shown in Figures $1 d$ and $2 d$,e; after culture, many E17-[ $\left[{ }^{3} \mathrm{H}\right]$ thymidinelabeled cells had moved through the earlier-born BrdU-labeled cells to occupy more superficial positions, as they would have done in vivo (in Fig. 1d, note that the thymidine label was rather scattered, as a few E17-labeled cells did remain abnormally deep, below the cortical plate; this is analyzed further below, Fig. $8 c, d$, and indicates that migration in vitro was not as complete as in vivo). The pattern of innervation of the cortical slices by a cocultured thalamus was examincd after $10 \mathrm{~d}$ in vitro and scemed similar to that shown in Figure 3 in all cases. Bundles of thalamocortical fibers penetrated the cortical slices and ran below the cortical plate; most did not enter it. The inability of thalamocortical axons to innervate the cortical plate at E19 is in good agreement with the findings of Molnar and Blakemore (1991) and Bolz et al. (1993).

When cortical explants were cultured for $10 \mathrm{~d}$ either alone, with additional cortex, or with cerebellum, E13-labeled cells were absent in some sections (Fig. $1 e, 2 g$ ) and were only very sparse in others, confirming the results of Gillies and Price (1993b). At high magnification with no counterstaining, only a small amount of BrdU reaction product was seen in many sections, and much of it probably represented fragmented nuclei (Fig. 1f). The quantification of these observations is shown in Figure 4. The histograms demonstrate that in the presence of thalamic explants, many E13-born cells that would disintegrate in the absence of the thalamus were rescued (Fig. 4a). Those few E13-born cells that did survive without the thalamus (i.e., those with healthy-looking nuclear label) were relatively superficial, at the lower edge of the cortical plate (Fig. $4 b$ ). The distributions of E13-born cells surviving in controls with additional cortical explants or cerebellar slices were no different from that in Figure $4 b$, and peak densities were similarly low (see Fig. $2 g$ ). The mean peak densily was $4.8 \times$ $10^{3}( \pm 2.3 \mathrm{SEM})$ cells $\mathrm{mm}^{-3}$ with additional cortical explants and 

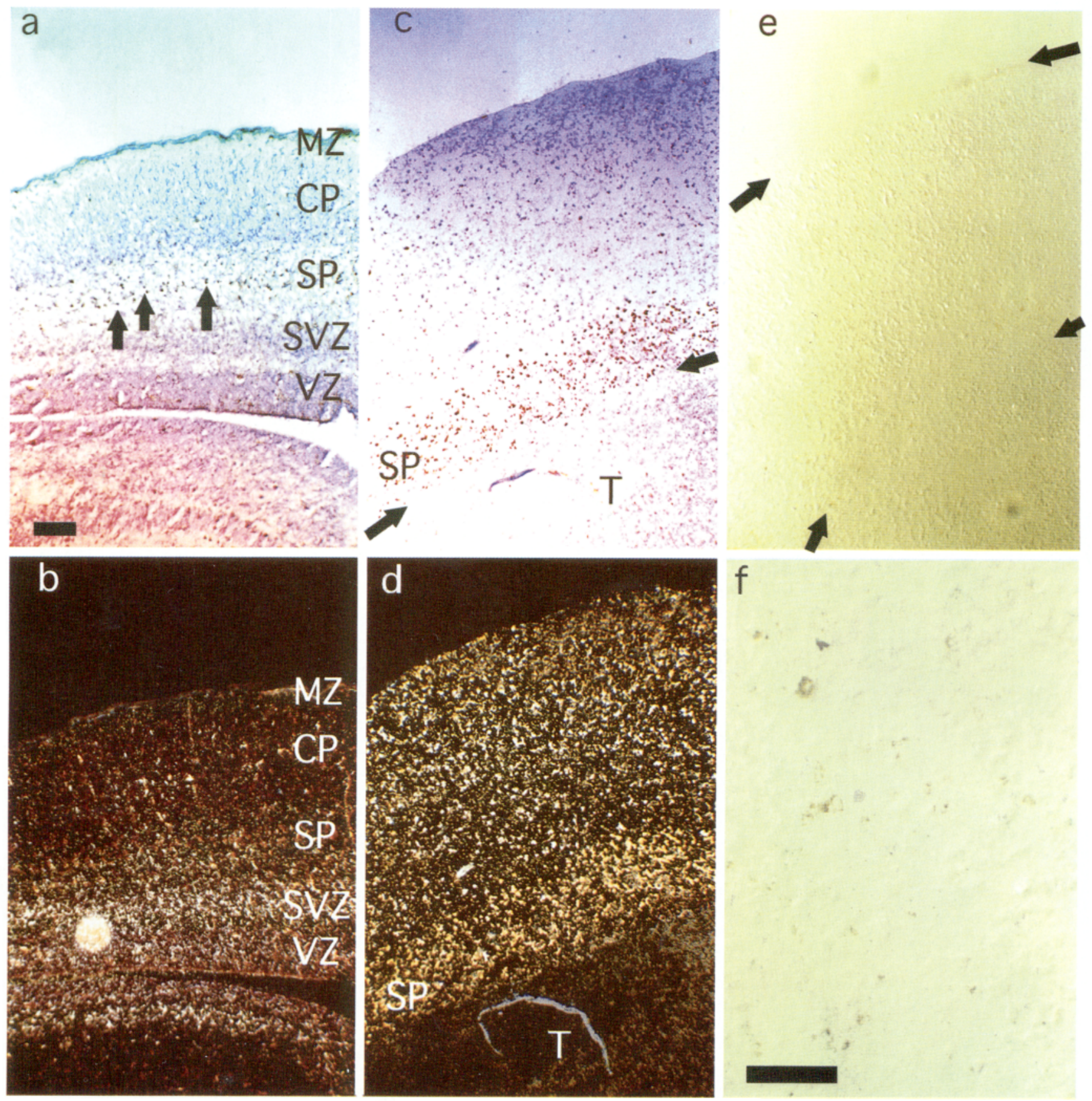

Figure 1. a, Bright-field photomicrograph of a parasagittal section of E19 cortex before culture, reacted to reveal BrdU labeling and then Nissl-stained. Most cells labeled with BrdU on E13 were in the subplate; a few were in the deepest part of the cortical plate (BrdU-labeled cells have dense brown nuclei; arrows point to examples). $b$, Mice injected with BrdU on E13 were also injected with tritiated thymidine on E17 to label layer 2 and 3 neurons. This shows a dark-field photomicrograph of the same slice of E19 cortex as in $a$. The high density of silver grains demonstrates the location of E17-labeled layer 2 and 3 neurons in the ventricular and subventricular zones. Note that the BrdU-labeled cells, which appear as dark dots under the illumination in $a$, can be seen here; they appear gold-colored and are mainly in the subplate, with a few in the deepest part of the cortical plate. $c$ and $d$, Photomicrographs demonstrate the appearance of E19 cortical slices after $10 \mathrm{~d}$ of culture with thalamic explants. As shown in $c$, many BrdU-labeled neurons were still present; most were in the subplate where they appeared as a band of brown-labeled cells. Arrows indicate the boundary between the thalamic and cortical explants. As shown in $d$, many layer 2 and 3 neurons have migrated into the cortical plate: compared with $b$, a large number of thymidine-labeled cells are in the top half of the slice. The yellow/gold labeling predominantly in the subplate in $d$ is from the BrdU-labeled cells shown in $c$. $e$, After culturing E19 cortical slices alone for $10 \mathrm{~d}$, nearly all the E13-labeled subplate neurons degenerated. Arrows indicate the upper and lower edges of the cortical plate. $f$, A higher-magnification view of $e$; only small amounts of BrdU reaction product are seen. $M Z$, Marginal zone; $C P$, cortical plate; $S P$, subplate; $S V Z$, subventricular zone; $V Z$, ventricular zone. Scale bars: $a-e, 50 \mu \mathrm{m} ; f, 25 \mu \mathrm{m}$. 

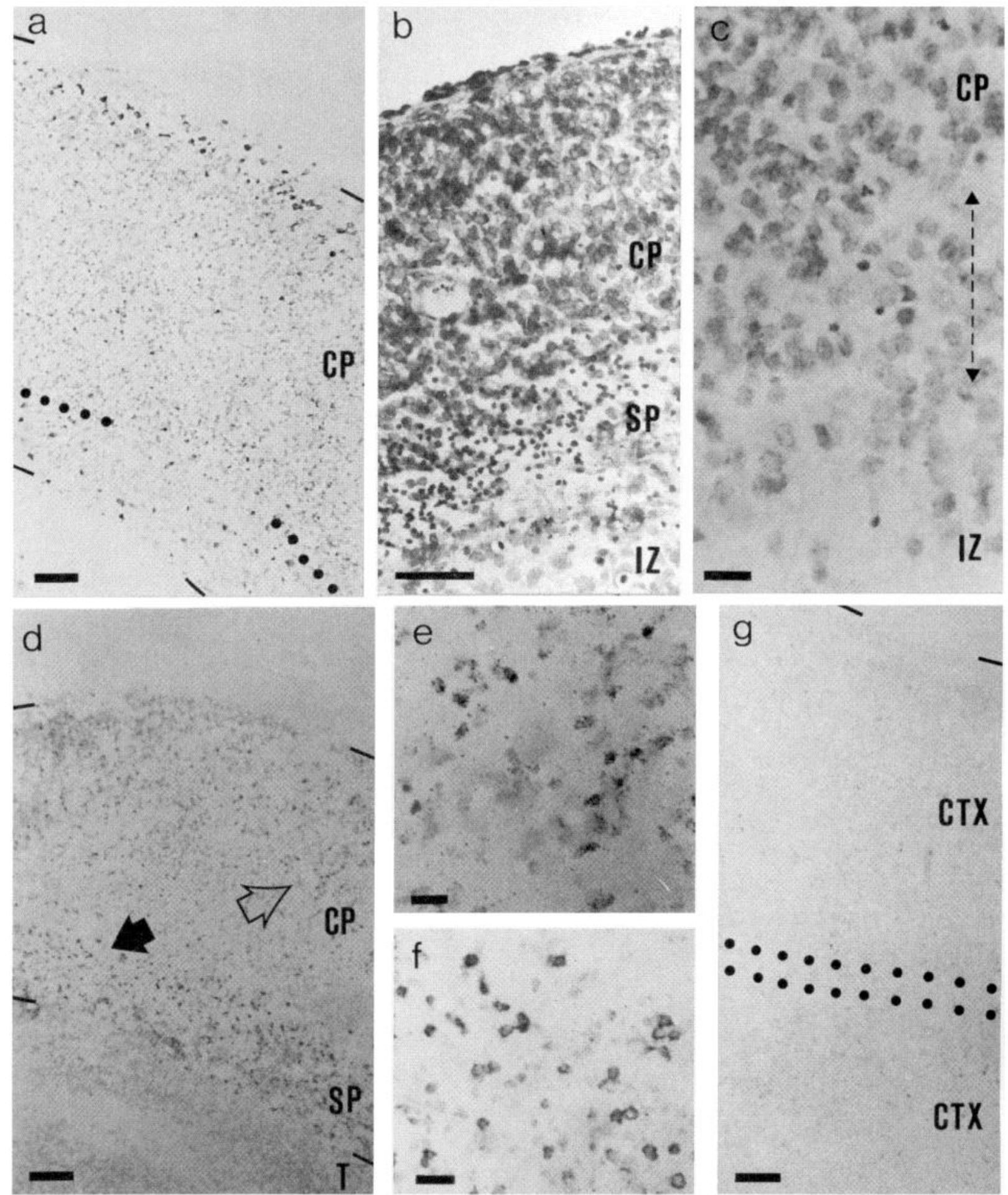

Figure 2. Bright-field photomicrographs of sections of cultured E19 cortex. $a$, Section of a slice of cortex that had been labeled with BrdU on E17 and cultured alone for $10 \mathrm{~d}$; the section is reacted for BrdU and Nissl-stained. Dark dots at the pial edge of the slice are BrdU-labeled cells. Dotted lines mark the lower edge of the cortical plate. $b$, Nissl-stained section of slice that had been cultured alone for $3 \mathrm{~d}$. Pyknotic cells were concentrated below the cortical plate (small dark dots). $c$, High-magnification view of the lower edge of the cortical plate in a $10 \mathrm{~d}$ Nissl-stained culture. The lower edge of the cortical plate is recognized by the transition from a region of high cell density to one of $\sim 50 \%$ lower density, which occurs over a depth of up to $\sim 50 \mu \mathrm{m}$ (double-headed arrow); the density increases again in the remains of the ventricular zone (Gillies and Price, 1993b). A few pyknotic cells remain (dark dots); many appear more degenerate than after $3 \mathrm{~d}$ in culture. $d$, Section of a slice of cortex that had been labeled with BrdU on E13 and with tritiated thymidine on E17 and cultured with thalamus for $10 \mathrm{~d}$. BrdU and tritiated thymidine-labeled cells were revealed, and the section was very lightly counterstained. BrdU-labeled cells were mainly in the subplate (dark dots); the dark dots in the cortical plate are tritiated thymidine-labcled cells. The groups of tritiated thymidinc-labeled cells indicated by the open arrow in $d$ are shown at higher magnification in $e$; note the typical appearance of the silver grains. The group of BrdU-labeled cells indicated by the solid arrow in $d$ is shown at higher magnification in $f . g$, Section of a slice of cortex, labeled with BrdU on E13, that had been cultured with another slice of cortex for $10 \mathrm{~d}$. Very few BrdU-labeled cells were present. The region between the dotted lines is where the two slices have fused. CP, Cortical plate; $C T X$, cortex; IZ, intermediate zone; $S P$, subplate; $T$, thalamus. Scale bars: $a, b, d, g, 50 \mu \mathrm{m} ; c, e, f, 15 \mu \mathrm{m}$. 


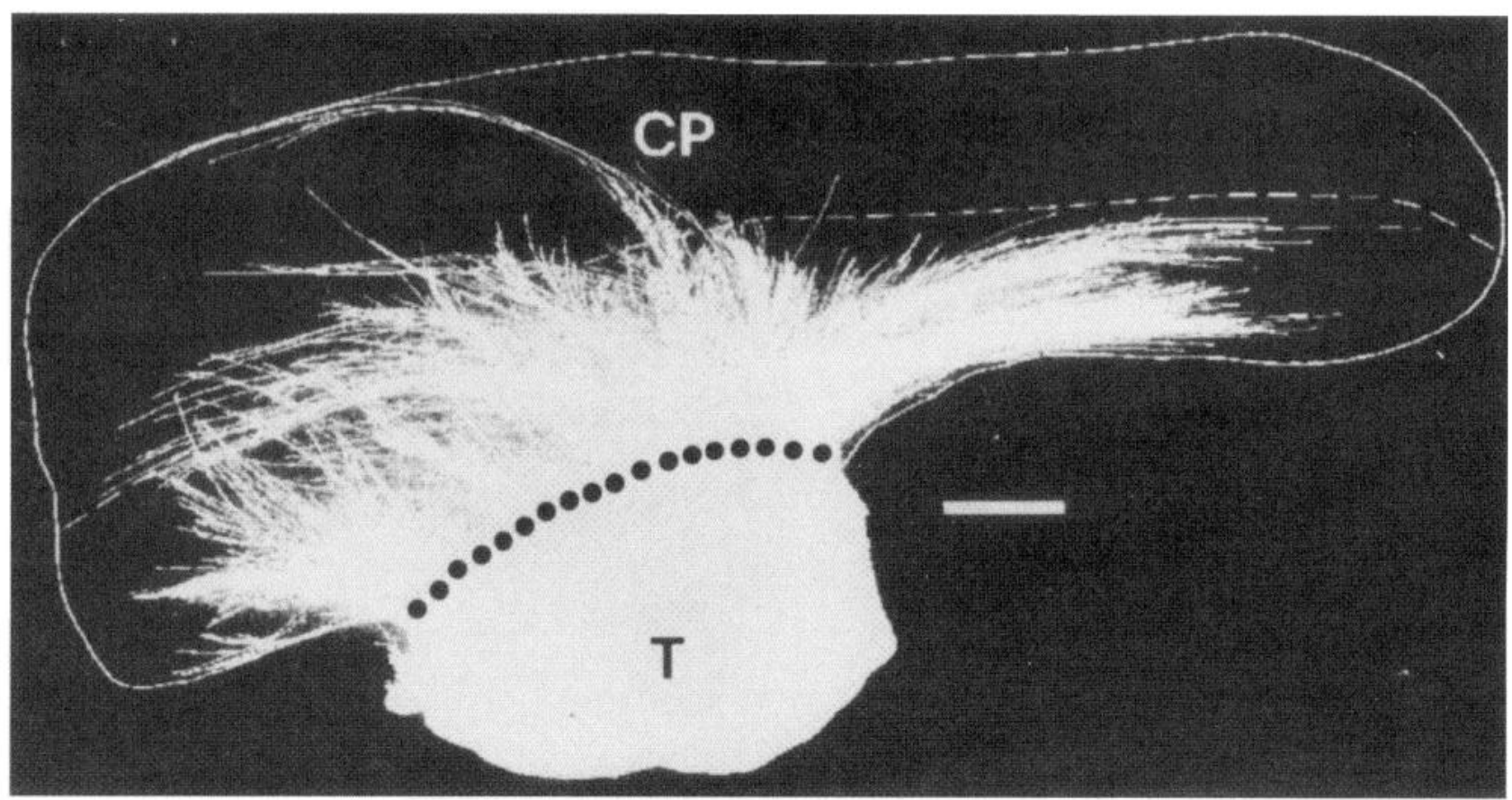

Figure 3. Camera lucida drawing of an E19 cortical slice cultured for $10 \mathrm{~d}$ with a thalamic explant. Thalamic growth was labeled with DiI. Broken line indicates the lower edge of the cortical plate $(C P)$. Dotted line is the border with the thalamus $(T)$. Scale bar, $200 \mu \mathrm{m}$.

$5.3 \times 10^{3}( \pm 4.4)$ cells $\mathrm{mm}^{-3}$ with cerebellum. The cerebellar explants did not innervate the cortical explants, although most cells in them remained viable.

\section{No influence of the thalamus on cell numbers in the cortical plate}

When E19 cortical explants were cultured alone for 3 and $10 \mathrm{~d}$, many viable cortical plate cells were seen (Fig. $2 a-c$ ). Migration of E17-labeled cells continued in these isolated explants, as is shown in Figure $2 a$. E17-born cells, which would have been below the cortical plate at the time of entry to culture (Fig. $1 b$ ), were seen around the pial edge of the slice after $10 \mathrm{~d}$ in culture. The cortical plate expanded at the expense of the intermediate, subventricular, and ventricular zones (Fig. $2 a$ ). After only $3 \mathrm{~d}$ in isolated culture (Fig. $2 b$ ), there were pyknotic cells in the slices. We calculated their mean densities at different depths in three sections through the center of each of four cultures to generate the histogram in Figure 5. The vast majority of these pyknotic cells were below the cortical plate (Figs. $2 b, 5$ ). After $10 \mathrm{~d}$ in culture, fewer pyknotic cells were seen. Those that remained seemed to be in a more advanced state of disintegration; that is, most had a less smooth, more fragmented profile (Fig. $2 c$ ). These data are compatible with those on the densities and positions of E13-born cells described above. They demonstrate that whereas pyknosis does occur early and at all depths in E19 cortical explants cultured alone (not surprisingly, given the inevitable trauma of tissue slicing), it is most intense in the subplate and below.

Figure 6 shows the average numbers of BrdU-labeled cells per 1-mm-wide strip through sections of cortex before culture, after coculture with a thalamic explant, or after culture with no other tissue. These histograms give an overview of the effects of culturing either with or without thalamic explants on the survival of cells born on E13, E14, E15, or E17. As was clear from the analyses in the previous section, the number of E13-born cells was signifi-

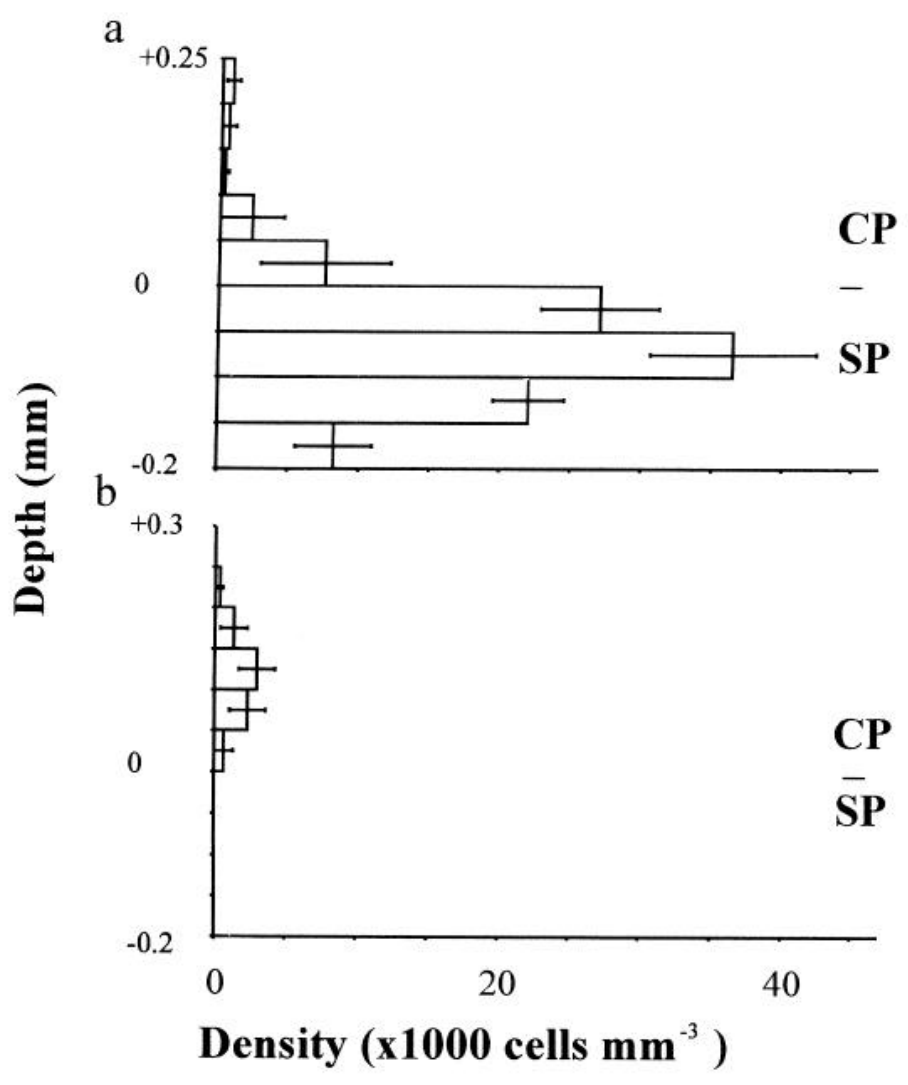

Figure 4. Histograms show the distributions of E13 BrdU-labeled neurons in cortical slices cultured $(a)$ with and $(b)$ without thalamic slices from E19 for $10 \mathrm{~d}$. Labeled cells were counted in $50-\mu \mathrm{m}$-wide bins through the depth of the slices above (positive values) and below (negative values) the lower edge of the cortical plate; values are mean \pm SEM $(n=6$ in all cases). $C P$, Cortical plate; $S P$, subplate. 


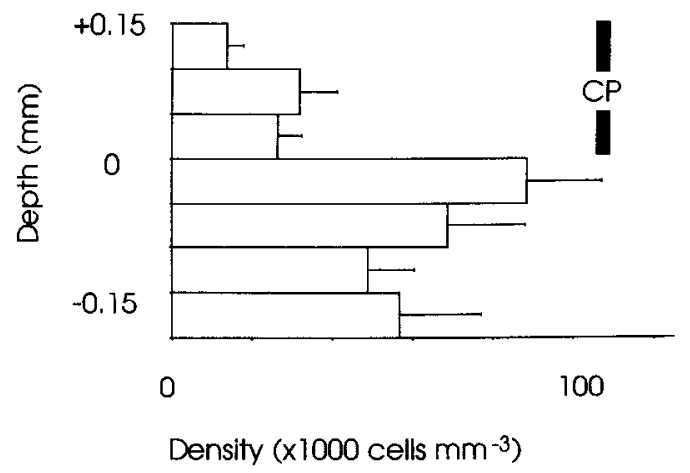

Figure 5. Mean densities ( + SEM; $n=4$ cultures) of pyknotic cells through the depth of E19 cortical slices cultured alone for $3 \mathrm{~d}$ (as in Fig. $2 b$ ). Bins are above (positive values) and below (negative values) the lower edge of the cortical plate $(C P)$.

cantly lower when no thalamic explant was present (compare column 2 with column 3 on left of Fig. 6). The numbers of E13-labeled cells in cortices cultured with additional cortex or with cerebellum were no different from those in cortices cultured alone. The numbers of E14-born, E15-born, or E17-born cells were not affected by coculture with a thalamic explant as opposed to culture alone (compare columns 2 and 3 for E14, 15, and 17-born cells in Fig. 6). This confirms that there was no influence of the thalamus on the number of cells that form the cortical plate itself. As is also apparent from Figure 6, culturing reduced the number of later-born cells, but not the number of earlier-born cells (compare columns 2 and 3 with column 1 for each age).

An important question that we considered in detail is whether cells that form layer 6 in vivo are dependent on the thalamus for their survival under the culture conditions used here. Figure 7 shows the distributions of E13-born cclls at E19, bcfore culture

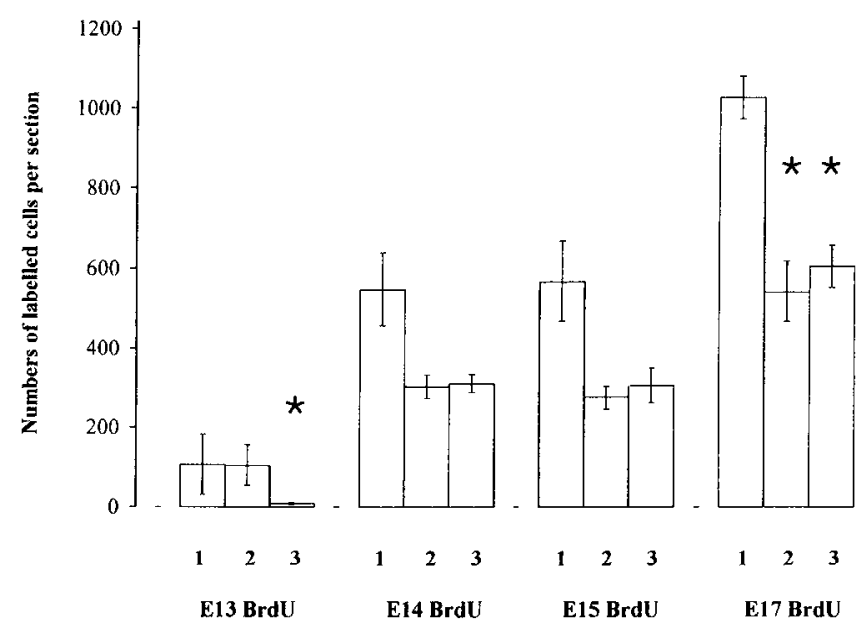

Figure 6. Histograms show the average numbers ( \pm SEM) of BrdUlabeled cells per section $(l)$ before culture on E19, (2) after culture from E19 for $10 \mathrm{~d}$ with a thalamic explant, and (3) after culture from E19 for 10 d without any other tissue. BrdU was injected on E13, E14, E15, or E17. Cells were counted in 1-mm-wide strips through the entire depth, from pia to ventricular zone, of each parasagittal section. Sections before culture were taken one third of the distance between the medial and lateral edges of the brain; after culture, they were from the center of each explant (see Materials and Methods). Asterisks indicate significant decreases $(p<0.01$; Student's $t$ test): after E13 injections, 3 is significantly lower than 1 and 2; after E17 injections, 2 and 3 are both significantly lower than 1 . At each age of injection: for column $1, n=4$ experiments; for columns 2 and $3, n$ $=6$ experiments each. a

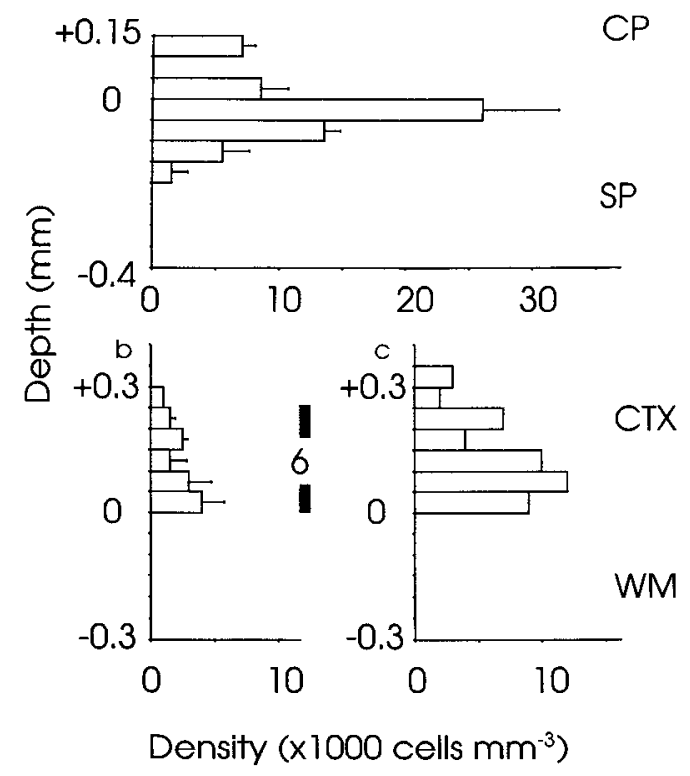

Figure 7. Mcan densities ( \pm SEM) of BrdU-labeled cells through the depth of $(a)$ E19 and $(b, c)$ P21 cortex. Bins are above (positive values) and below (negative values) the lower edge of $(a)$ the cortical plate $(C P)$ and $(b, c)$ layer 6 . In $a$, data from the full depth of the cortical plate are shown; in $b$ and $c$, only the data from the deep part of the cortex are shown, because there was no label elsewhere. In $a$ and $b$, cells were labeled on E13: $a$, at E19, most label was in the subplate $(S P)$, and only some was in the cortical plate and marginal zone (counts for the marginal zone were included in the $+0.1-0.15$ bin) ( $n=4$ mice); $b$, at P21, a smaller number of E13-labeled cells was confined mainly to layer $6(n=4$ mice). $c$, Data from E14 injections of $\mathrm{BrdU}(n=2$ mice): at P21 the majority of labeled cells was in layer 6 with some in layer 5 , in agreement with previous findings (Gillies and Price, 1993a). The vertical bar indicating the depth of layer 6 at P21 applies to $b$ and $c$. $C T X$, Cortex; $W M$, white matter.

(Fig. 7a), and of E13- and E14-born cells at P21 in vivo (Fig. 7b,c). Although the majority of E13-born cells was distributed in the subplate at E19, with some in the overlying cortical plate (Fig. 7a), by $\mathrm{P} 21$ only a low density of these cells remained, confined to layer 6 of the cortex (Fig. $7 b$ ). At P21, the majority of E14-born cells formed layer 6 with some contributing to layer 5 (Fig. 7c). Figure $8 a$ shows the distribution of E14-born cells at E19: the vast majority were in the cortical plate.

Taken together, these data indicate that without a thalamic explant, only those E13-born cells that migrate into the cortical plate, where they contribute to layer 6 , survive (compare Fig. $4 a, b$ with Fig. 7a,b). E14-born cells, which are in the cortical plate by F.19 (Fig. 8a) and contribute to cortical layer 6 and to a lesser extent layer 5 (Fig. 7c), survive equally well whether a thalamic explant is present or not (Fig. 6). Thus, cells destined to form layer 6 , which projects to the thalamus in vivo, do not seem to be dependent on the thalamus for their survival at E19, even though some cells born on E13 have the same birthdate as cells that form the subplate and do become dependent.

\section{DISCUSSION}

The preparation of an organotypic explant inevitably causes the death of some cells throughout the explant. Some of this death is a consequence of the trauma of sectioning (Rennie et al., 1994). In this study, however, we found a disproportionately large amount of cell death below the cortical plate in late embryonic 
a

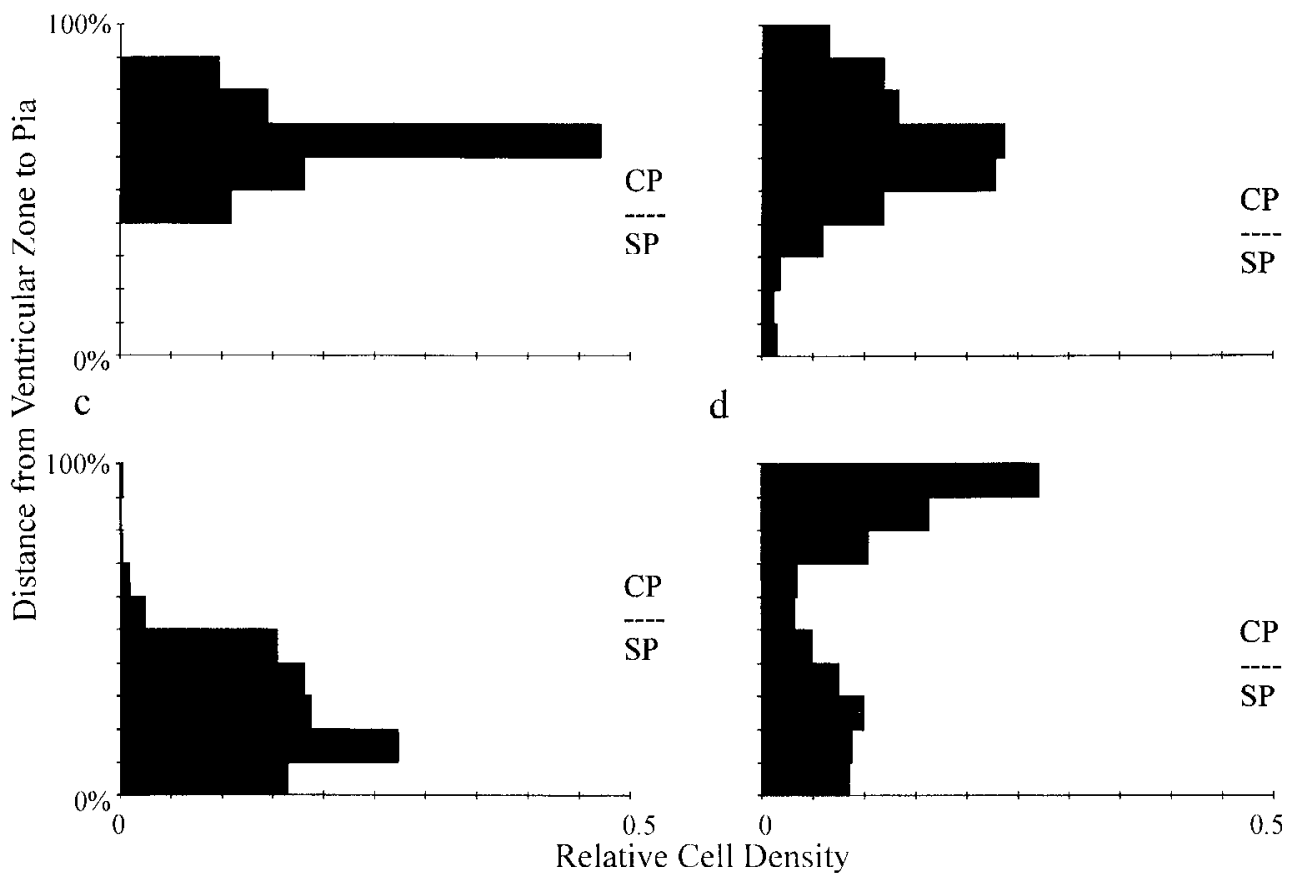

b

Figure 8. Histngrams illustrating the relative densities of BrdU-labcled neurons within E19 cortical slices before and after culture for $10 \mathrm{~d}$ with a thalamic explant. The $y$-axes of the histograms represent relative depths through the slices ( $100 \%$ represents the pial edge). $a$, Cells labeled on E14 before culture; most are already in the cortical plate $(n=4$ mice). $b$, After $10 \mathrm{~d}$ in culture, most of these E14-labeled cells remain centered at the same relative positions but are more widely distributed ( $n=6$ cultures). $c$, At E19, cells labeled with BrdU on E17 are mainly in the ventricular zone $(n=4$ mice). $d$, After $10 \mathrm{~d}$ in culture, many of the E17-labeled cells have migrated into the cortical plate, although a significant number have remained in the ventricular zone ( $n=6$ cultures). $C P$, Cortical plate; $S P$, subplate. cortical explants that had been cultured alone. The use of BrdU to label specific populations of cells on the basis of their birthdates indicated that there was a selective loss of neurons in the subplate of these isolated slices. By contrast, many cortical plate cells, including those of layer 6 , remained viable and many of those destined for the superficial layers continued to migrate under these conditions. Coculturing with either thalamic or control explants of cerebellum or cortex confirmed that the presence of the thalamus, and not merely the presence of additional tissue, promoted the survival of cells of the subplate but not cells in the cortical plate (whose survival, in any case, was affected less in E19 cortical explants cultured alone; see below).

One important observation was that even without a cocultured thalamus, not all cells born on E13 died in isolated cortical explants. Our results suggest that those E13-born cells that were in the cortical plate at E19 survived. Both this and previous studies have shown that in the mouse, not only cells destined for the subplate but also some cells that survive to form layer 6 are born on E13 (Wood et al., 1992). Thus, whether a cortical progenitor becomes dependent on the thalamus for its survival may not be determined by its birthdate; rather, it may be determined by position-dependent factors that impinge on it once it has migrated. These findings are in agreement with previous studies that have found insensitivities of cortical efferent cells from deep layers to neonatal removal of their targets in vivo (Pallas et al., 1988; Windrem and Finlay, 1991).

The subplate is an unusual structure that has attracted much attention in recent years. Unlike the overlying cortical plate, current evidence indicates that many of its cells are fated to die after playing a crucial role in guiding thalamocortical and possibly other long-range cortical projections to their appropriate targets (Ghosh et al., 1990; Ghosh and Shatz, 1992a; Allendoerfer and Shatz, 1994). The subplate also seems important for the later refinement of cortical afferents (Ghosh and Shatz, 1992b). The size of the subplate is species-dependent. Larger subplates are found in larger brains, and in rodents the subplate is relatively small (Wood et al., 1992; Allendoerfer and Shatz, 1994). The proportion of subplate cells that die during development may also be species-dependent. In the cat, almost all subplate cells die by 4 months postnatally (Allendoerfer and Shatz, 1994), whereas in the hamster, although most subplate cells die, a significant proportion may persist into adulthood (Woo et al., 1991). There is some controversy over the amount of cell death in the subplate of the rat; several studies have indicated that developmentally regulated subplate cell death probably does occur in this species (for review, see Allendoerfer and Shatz, 1994), although findings by Valverde et al. (1995) suggested that at least from birth on, it involves relatively few cells. In the mouse, the subject of this present study, the evidence is that many subplate cells die (Wood et al., 1992; Gillies and Price, 1993h). What determines the death or survival of subplate cells in vivo is unclear. Certainly, the time of their death may not rely on a cell-autonomous endogenously timed death program, because the timing of subplate death can be manipulated readily both in vitro and in vivo. For example, subplate death occurs more rapidly in cortical slices cultured alone than it does in vivo (Wood et al., 1992; Gillies and Price, 1993b). Furthermore, in vivo lesions of the thalamocortical pathway can alter the time at which subplate cells die (Molnar et al., 1991). Finally, as our present experiments show, one can alter the timing of subplate death in vitro by altering the culture conditions (i.e., by adding thalamic tissue; serum-supplemented medium will also keep subplate cells alive) (Hohn et al., 1993; K. Gillies and D. J. Price, unpublished observations). These experiments suggest that a change in the trophic support that subplate cells receive from subcortical structures may contribute to a change in their viability in vivo.

Our first thought was that in vivo, subplate neurons may obtain thalamic factors by the well established mechanism of retrograde transport along their axons (Korsching, 1993); however, recent observations mitigate against this possibility. Although some subplate axons may project to or through the internal capsule (De Carlos and O'Leary, 1992) and might even pioneer this pathway 
for subsequent layer 5 and 6 fibers (McConnell et al., 1989), it seems that few subplate axons actually innervate nuclei within the dorsal thalamus itself (Clasca et al., 1994, 1995; Molnar, 1994; Molnar and Blakemore, 1995). Thus, if the thalamus is not a major target, most subplate neurons would probably not acquire thalamic factors retrogradely. On the other hand, it is well documented that thalamic axons invade the subplate (Ghosh and Shatz, 1992a), as occurred in our in vitro experiments (and did not occur with control explants from the cerebellum). Thus, it is possible that thalamic factors are transported anterogradely along thalamocortical axons into the subplate. There is a precedent for the anterograde transport of trophic factors within the visual system, from the retina to the tectum (Catsicas et al., 1992). With this in mind, we propose the following sequence of events.

At approximately E16-E17 in rodents, thalamocortical axons reach the subplate (Catalano et al., 1991), where at least some may form transient synaptic contacts (Friauf et al., 1990; Herrmann et al., 1994). At this time, thalamic factors transported into the subplate may maintain its viability; however, as thalamic axons leave the subplate to innervate the overlying cortical plate, perhaps because of the upregulation of growth-promoting substances in the cortical plate (Bolz et al., 1993; Tuttle et al., 1995), they take with them their trophic support. Consistent with this hypothesis is the observation that the onset of subplate death in mice occurs after the time when the subplate starts to clear of thalamic innervation (Wood et al., 1992). Moreover, it should be noted that in our culture experiments, as in those of others (Molnar and Blakemore, 1991; Bolz et al., 1993), most of the invading thalamocortical neurites did not enter the E19 cortical plate even after 10 $\mathrm{d}$ in vitro, and their continued presence in the subplate may have maintained the cells of this region throughout the culture period.

Other mechanisms may also contribute to the timing of subplate death in vivo, but they seem less satisfactory as complete explanations. For example, the innervation of subplate cells (rather than the withdrawal of innervation) may push them toward death, possibly by exposing them to large amounts of glutamate, which is known to be toxic at high concentrations (Lipton and Kater, 1989). This theory would demand an explanation of why subplate cells should be more sensitive to the effects of innervation than the cortical plate, which is clearly not killed by innervation. A loss of trophic support from the thalamus might be one explanation. It seems unlikely that the thalamocortical contribution to the afferent innervation of subplate cells kills them, because subplate death occurs after thalamocortical axons start to leave this region (see above). This does not exclude the possibility that other afferent projections to the subplate play a role in triggering the death of these cells (e.g., those from other cortical areas that develop later).

It was interesting that at the late embryonic stage studied here, the viability of cortical plate neurons, including those of layers 6 and 4 that project to and receive innervation from the thalamus, was unaffected by the presence or absence of a cocultured thalamus. At this age, the survival of most cortical plate cells may be promoted by cortical factors; clearly, cortical cells that can survive without the thalamus at E19 may develop a dependency on the thalamus at later ages. It is also interesting to note that during the $10 \mathrm{~d}$ culture period, either with or without thalamus, some cell death did occur among the later-born cortical plate cells (in particular among E17-born cells, whose numbers after culture fell significantly; Fig. 6). Mirroring these findings, Windrem and Finlay (1991) showed that by the end of the first postnatal week in the hamster (an age that corresponds approximately with the end of the culture period used here), cell death is seen across all cortical layers in vivo, with a high incidence among cells destined for the superficial layers (i.e., E17-born cells) (Finlay and Slattery, 1983). Windrem and Finlay (1991) also demonstrated that neonatal lesions of the thalamus significantly increased cell death among P7 cells destined to form the superficial layers but not among P7 cells destined for the other layers. Thus, with regard to all layers except the most superficial ones, these previous in vivo findings are similar to our in vitro observations. The fact that the loss of the thalamus in the experiments of Windrem and Finlay (1991) increased cell death in the superficial layers, whereas replacing the thalamus in our experiments did not increases the survival of these cells, argues that the thalamus may enhance the survival of some superficial layer cells but that it is not sufficient to do so. Although the thalamus may provide all that is needed to promote survival for E13-born cells, at least some E17-cells may require factors that are lost when our cultures are performed. For example, influences from surrounding cortical areas are good candidates because corticocortical cells project to the superficial cortical layers, and there is evidence that they provide trophic support specifically to those layers (Haun and Cunningham, 1993; Price, 1995). These factors may act synergistically with thalamic influences. Finally, Windrem and Finlay (1991) showed that neonatal lesions of the thalamus led to a selective loss of layer 4 cells by adulthood and offered two possible explanations: either there was death of layer 4 cells, or they were respecified during postnatal development as replacements for dead cells in more superficial layers. Our results argue in favor of the second explanation and against the dependence of very early layer 4 cells on the thalamus for their survival.

Overall, our results suggest that the thalamus has important trophic (i.e., survival-promoting) effects on the subplate at the end of embryogenesis. These may contribute to the regulation of subplate survival in vivo. The next important task will be the identification of the molecules mediating these interactions.

\section{REFERENCES}

Allendoerfer KL, Shatz CJ (1994) The subplate, a transient neocurtical structure: its role in the development of connections between the thalamus and cortex. Annu Rev Neurosci 17:185-218.

Bayer SA, Altman J (1991) Neocortical development. New York: Raven.

Bolz J, Gotz M, Hubener M, Novak N (1993) Reconstructing cortical connections in a dish. Trends Neurosci 16:310-316.

Bolz J, Novak N, Gotz M, Bonhoeffer T (1990) Formation of targetspecific neuronal projections in organotypic slice cultures from rat visual cortex. Nature 346:359-363.

Catalano SM, Robertson RT, Killackey HP (1991) Early ingrowth of thalamocortical afferents to the neocortex of the prenatal rat. Proc Natl Acad Sci USA 88:2999-3003.

Catsicas M, Pequignot Y, Clarke PGH (1992) Rapid onset of neuronal death induced by blockade of either axoplasmic transport or action potentials in afferent fibers during brain development. J Neurosci $12: 4642-4650$.

Clasca F, Angclucci A, Sur M (1994) Layer 5 neurons establish the first cortical projection to the dorsal thalamus in ferrets. Soc Neurosci Abstr 20:98.1.

Clasca F, Angelucci A, Sur M (1995) Layer-specific programs of development in neocortical projection neurons. Proc Natl Acad Sci USA 92:11145-11149.

De Carlos JA, O'Leary DDM (1992) Growth and targeting of subplate axons and establishment of major cortical pathways. J Neurosci 12:1194-1211.

del Rio JA, Soriano E (1989) Immunocytochemical detection of 5'bromodeoxyuridine incorporation in the central nervous system of the mouse. Dev Brain Res 49:311-317.

Finlay BL, Slattery M (1983) Local differences in amount of early cell death in neocortex predict adult local specializations. Science 219:1349-1351. 
Friauf E, McConnell SK, Shatz CJ (1990) Functional synaptic circuits in the subplate during fetal and early postnatal development of cat visual cortex. J Neurosci 10:2601-2613.

Ghosh A, Shatz CJ (1992a) Pathfinding and target selections by developing geniculocortical axons. J Neurosci 12:39-55.

Ghosh A. Shatz CJ (1992b) Involvement of subplate neurons in the formation of ocular dominance columns. Science 255:1441-1443.

Ghosh A, McConnell SK, Shatz CJ (1990) Requirement for subplate neurons in the formation of thalamocortical connections. Nature 347:179-181.

Gillies K, Price DJ (1993a) The fates of cells in the developing cerebral cortex of normal and methylazoxymenthanol acetate-lesioned mice. Eur $J$ Neurosci 5:73-84

Gillies K, Price DJ (1993b) Cell migration and subplate loss in explant cultures of murine cerebral cortex. NeuroReport 4:911-914.

Haun F, Cunningham TJ (1993) Recovery of frontal cortex-mediated visual behaviors following neurotrophic rescue of axotomized neurons in medial frontal cortex. J Neurosci 13:614-622.

Herrmann K, Antonini A, Shatz CJ (1994) Ultrastructural evidence for synaptic interactions between thalamocortical axons and subplate neurons. Eur J Neurosci 6:1729-1742.

Hohn A, Allendoerfer KL, Toroian-Raymond A, Shatz CJ (1993) Survival of subplate neurons in cultures of developing neocortex. Soc Neurosci Abstr 19:620.7.

Korsching S (1993) The neurotrophic factor concept: a reexamination. I Neurosci 13:2739-2748

Lipton SA, Kater SB (1989) Neurotransmitter regulation of neuronal outgrowth, plasticity and survival. Trends Neurosci 12:265-270.

Lotto RB, Price DJ (1994) Evidence that molecules influencing axonal growth and termination in the developing geniculocortical pathway are conserved between divergent mammalian species. Dev Brain Res $81: 17-25$.

Lotto RB, Price DJ (1995) The stimulation of thalamic neurite outgrowth by cortex-derived growth factors in vitro; the influence of cortical age and activity. Eur J Neurosci 2:318-328.

McConnell S, Ghosh A, Shatz CJ (1989) Subplate neurons pioneer the first axon pathway from the cerebral cortex. Science 245:978-982.

Molnar Z (1994) Multiple mechanisms in the establishment of thalamocortical innervation. $\mathrm{PhD}$ thesis, University of Oxford.
Molnar Z, Blakemore C (1991) Lack of regional specificity for connections formed between thalamus and cortex in coculture. Nature 351:475-477.

Molnar Z, Blakemore C (1995) Guidance of thalamocortical innervation In: Development of the cerebral cortex. Ciba Foundation Symposium 193, pp 127-140. Wiley: Chichester.

Molnar Z, Yee K, Lund R, Blakemore C (1991) Development of rat thalamus and cerebral cortex after embryonic interruption of their connections. Soc Neurosci Abstr 17:305.3.

Pallas SL, Gilmour S, Finlay BL (1988) Control of cell number in the developing neocortex. I. Effects of early tectal ablation. Dev Brain Res 43:1-11.

Price DJ (1995) Lesions of area 17 in newborn kittens cause selective changes in the development of area 18. NeuroReport 7:201-204.

Rennie S, Lotto RB, Price DJ (1994) Growth-promoting interactions between the murine neocortex and thalamus in organotypic co-cultures. Neuroscience 61:547-654.

Romijn HJ, van Juizen F, Wolters PS (1984) Towards an improved serum-free chemically defined medium for long-term culturing of cerebral cortex tissue. Neurosci Biobehav Rev 8:301-334.

Smart IMH, Smart M (1982) Growth patterns in the lateral wall of the mouse telencephalon. I. Autoradiographic studies of the histogenesis of the isocortex and adjacent areas. J Anat 134:273-298.

Tuttle R, Schlaggar BL, Braisted JE, O'Leary DDM (1995) Maturationdependent upregulation of growth-promoting molecules in developing cortical plate controls thalamic and cortical neurite growth. $J$ Neurosci 15:3039-3052.

Valverde F, Lopez-Mascaraque L, Santacana M, De Carlos JA (1995) Persistence of early-generated neurons in the rodent subplate: assessment of cell death in neocortex during early postnatal period. J Neurosci 15:5014-5024.

Windrem MS, Finlay BL (1991) Thalamic ablations and neocortical development: alterations of cortical cytoarchitecture and cell number. Cereb Cortex 1:230-240.

Woo TU, Beale JM, Finlay BL (1991) Dual fate of subplate neurons in a rodent. Cereb Cortex 1:433-443.

Wood JG, Martin S, Price DJ (1992) Evidence that the earliest generated cells of the murine cerebral cortex form a transient population in the subplate and marginal zone. Dev Brain Res 66:137-140. 